\title{
MAKNA KISAH NUH AS DALAM AL-QUR'AN (PERSPEKTIF HERMENEUTIKA FILOSOFIS)
}

\author{
Muhammad Rusydi \\ Fakultas Ushuluddin dan Humaniora \\ Universitas Islam Negeri Antasari Banjarmasin \\ madibiqbal@gmail.com
}

\begin{abstract}
:
The writing discusses story of Noah (peace be upon him) in the Quran. The story will be approached by philosophical hermeneutics is conceived by Heiddegger and Gadamar. The main questions of the article are why and how the meaning of the story for Arabic people especially and for Moslem (buman kind) generally. Finally, the result shows that Prophet Nub is one of important ancestors for Arabic people and those people had listened and seen some historical events related to this prophet and his people. Moreover, the story teachs human being to surrender to Allah as it will lead them to appreciate all creations in this universe.
\end{abstract}

Keywords: Story of Noah, Arabic people, Human being, Creations, Meaning

\section{Pendahuluan}

Beberapa waktu lalu, Banjarmasin post dengan headline "Bumi Kini Tidak Lagi Sendiri" menampilkan berita tentang ditemukannya planet Kepler452b yang dianggap sebagai saudara tua bumi. ${ }^{1}$ Menanggapi berita ini, tiba-tiba terjadi dialog antara para pembaca. Seorang pembaca mengatakan, "ada-ada saja NASA ini, pikirannya cuma mengkhawatirkan bumi jika kiamat sehingga bisa lari ke planet lain”. Saat itu saya teringat dengan film 2012, yang memprediksikan bahwa kiamat akan terjadi pada tahun itu sesuai dengan ramalan suku Aztec. Kemudian, pembaca lain berpendapat, "mungkin saja planet yang ditemukan itu adalah planet bekas terjadinya banjir besar yang menimpa kaum Nuh as, kemudian Nabi Nuh as dan kaumnya "mendarat" di bumi yang sekarang ini". Beberapa pendapat memang ada yang berpendapat bahwa banjir besar yang menimpa Nabi Nuh as itu bersifat global, meskipun

\footnotetext{
${ }^{1}$ Redaksi, "Bumi Kini Tidak Lagi Sendiri," Banjarmasin Post, July 26, 2015, hlm.1. 
pendapat yang lain mengatakan sebaliknya bahwa banjir itu hanya lokal, di daerah Mesopotamia, lembah Tigris dan Eufrat. ${ }^{2}$

Terlepas dari dialog pembaca Banjarmasin post di atas, kisah Nabi Nuh as memang kisah yang spektakuler dan direkam oleh sejarah. Islam sendiri di dalam al-Qur'an menyebutkan kisah ini, baik secara global maupun detail dari berbagai surah. Nabi Nuh as, dalam versi Islam, juga bukanlah seorang nabi biasa. Ia dimasukkan dalam kategori Nabi-Nabi Ulul 'Azmi, sebuah gelar istimewa kenabian yang diberikan kepada nabi-nabi yang memiliki kedudukan yang khusus karena ketabahan dan kesabaran yang luar biasa dalam menyebarkan ajarannya, selain Nabi Ibrahim as, Musa as, Isa as, dan Muhammad Saw.

Selanjutnya, kisah Nabi Nuh as dan kisah lain yang diulang-ulang (tikrār) pada beberapa surah dan ayat dalam al-Qur'an, menurut Mannā' alQaț̣ān, memiliki beberapa maksud, diantaranya adalah untuk menunjukkan kualitas balägah al-Qur'an yang tinggi, untuk peneguhan dan penguatan makna kisah dalam jiwa, serta untuk menunjukkan adanya perbedaan tujuan pada berbagai penceritaan. ${ }^{3}$

Oleh karena itu, kisah Nuh as sebagai bagian dari rantai kenabian dan kerasulan serta direkam oleh al-Qur'an selain menarik untuk dikaji juga perlu untuk dimaknai. Dalam konteks tulisan ini, penulis berupaya memaknai kisah ini dari sudut pandang hermeneutika filosofis. Sebagaimana maklum, hermeneutika paling tidak bisa dibagi menjadi tiga ${ }^{4}$ yakni pertama, hermeneutika metodologis Schelaimacher yang menekankan aspek gramatikal dan psikologi ${ }^{5}$ dan hermeneutika metodologi sosial Whilhem Dithey. ${ }^{6}$ Kedua,

${ }^{2}$ Harun Yahya, Pustaka Sains Populer Islami 8: Jejak Bangsa-Bangsa Terdahulu (Bandung: Dzikra, 2004.), hlm. 22-25.

${ }^{3}$ Mannā' al-Qațạn, Mabāhith Fì “Ulūm Al-Qur"ān (tt.: al-Manshūrāt al-'Aṣr al-Ḥadith, 1973), hlm. 308.

${ }^{4}$ Untuk klasifikasi hermeneutika ini lihat Josef Bleicher, Contemporary Hermeneutics (London: Routledge \& Kegan Paul, 1980).

5 Schleiermacher stressed both grammatical, and technical or psychological, interpretation. The latter required identification with the mind-set of author, a radical principle since his main application of hermeneutics was to scripture. Beyond scripture, however, his techniques applied to any individual work cast in language and, beyond language, to all human manifestations, including conversations and work of art. E Sumaryono, Hermeneutika: Sebuab Metode Filsafat (Yogyakarta: Kanisius, 2002), hlm. 54-60. 
hermeneutika filosofis yang diwakili oleh Martin Heidegger dan Gadamer. Ketiga, hermeneutika kritis yang diwakili oleh Habermas yang menekankan pada aspek pemahaman kritis yang bernuansa ideologis.

Hermeneutika Heidegger dan Gadamer sebagai penerusnya disebut filosofis karena ia mengandaikan bahwa paham (mengerti) adalah status eksistensial (ontologis) manusia. ${ }^{7}$ Singkatnya, Dasein adalah verstehen. Oleh karena itu, manusia sebelum memahami atau memaknai, ia telah memiliki prapemahaman untuk memahami, kemudian ketika pra-pemahaman bertemu pemahaman dunia teks maka hal ini menghasilkan pemahaman yang baru. ${ }^{8}$

Jika berdasarkan Heidegger digambarkan bahwa pembacaan atau penafsiran selalu merupakan pembacaan ulang atau penafsiran ulang, sehingga memahami lagi teks yang sama secara baru dengan makna yang baru pula, maka pada Gadamer digambarkan langkah-langkah meraih pemahaman atas suatu teks: pertama, penafsir harus menyadari bahwa dia diliputi oleh sejarahnya sendiri yang mungkin mempengaruhi penafsirannya terhadap teks (bistorically effected consciousness). Kedua, menyadari adanya pra-pemahaman (preunderstanding) terhadap teks yang ditafsirkan. Ketiga, penafsir harus berupaya memperbarui pra-pemahamannya (fusion of horizons). Keempat, makna yang diterapkan adalah "makna yang berarti" (meaningfull sense) atau pesan yang lebih berarti daripada sekadar makna literal. ${ }^{10}$

Dengan demikian kisah Nabi Nuh as berupaya saya maknai sebagaimana konstruksi di atas.

'Perbedaan mendasar antara Schleiermacher dengan Dilthey adalah jika Schleiermacher menggunakan pendekatan gramatikal dan psikologikal, maka Dilthey dalam hermeneutikanya menekankan data dan riset untuk meminimalisir faktor subjektif. Ibid.

${ }^{7}$ Bandingkan ungkapan Bleicher: "Hermeneutic philosophy focuses not on the methodology of the Geisteswissenchaften, but on their relationship to the whole of our experience of the world; by evidencing understanding as a fundamental characteristic of existence. It does not intend to restrict the disciplined and skilled understanding of texts, but only hopes to free it from a false selfunderstanding”. Bleicher, Contemporary Hermeneutics, hlm 120.

${ }^{8}$ Kees Bertens, Filsafat Barat Abad XX: Inggris-Jerman (Jakarta: Gramedia, 1990), hlm 225.

${ }^{2}$ Faisal Attamimi, "Hermeneutika Gadamer Dalam Studi Teologi Politik," Hunafa: Jurnal Studia Islamika 9, no. 2 (Desember 2012), hlm. 284.

${ }^{10}$ Aat Hidayat, "Epistemologi Hermeneutik Hans-Georg Gadamer: Menyelami Kedalaman Tradisi, Menuai Kelezatan Makna," n.d., https://aathidayat.wordpress.com. Diakses pada 21 Agustus 2015 


\section{Pembahasan}

\section{Kisah Nabi Nuh As dalam al-Qur'an}

Dalam al-Qur'an ditemukan beberapa surah dan ayat yang berbicara tentang kisah Nabi Nuh as ini. Surah dan ayat tersebut diantaranya adalah; alA'rāf (7): 59-64, Yüuns (10): 71-74, Ḥūd (11): 25-49, al-Isrāa (17): 3, al-Anbiyā (21): 76-77, al-Mukminūn (23): 23-32, Al-'Ankabūt (29) : 14-15, al-Ṣāfăt (37): 75-82, dan Nūh (71): 1-28. ${ }^{11}$ Dari seluruh surah ini, surah Ḥūd (11): 25-49 dan Nūh (71): 1-28 yang menggambarkan kisah lebih detail dibandingkan surah-surah lain.

Secara ringkas, al-Qur'an menyimbolkan Nabi Nuh as dan pengikutnya sebagai simbol kebaikan, sementara kaumnya menjadi simbol kejahatan. Oleh karena Nabi Nuh as memiliki hikmah kebaikan maka ia memiliki kewajiban untuk menyebarkan kebaikan tersebut dengan berbagai usaha agar kaumnya juga mendapatkan hikmah tersebut. Sayangnya, kaumnya telah diliputi oleh sifat dzalim, kafir dan tertutup mata hatinya sehingga setiap ajakan Nabi Nuh as selalu diabaikan bahkan diejek. Akhirnya, kaum Nabi Nuh as yang menentangnya diazab Allah dengan banjir besar yang menghancurkan seluruh wilayah mereka.

\section{Nuh As dan Kondisi Masyarakatnya}

Dalam agama Islam, Nabi Nuh as adalah nabi ketiga sesudah Adam dan Idris. Nabi Nuh as adalah keturunan kesembilan dari Nabi Adam as atau generasi kesepuluh. Ayahya adalah Lamik (Lamaka) bin Mutawasylah bin Idris bin Yarid bin Mahlail bin Qainan bin Yanusyi bin Syits bin Adam as. ${ }^{12}$ Secara ringkas al-Razi menyebutkan keturunan Nabi Nuh as ini adalah Nuh bin Lamik (Lamaka) bin Mutawasylah bin Akhnukh (Enouch), nama Nabi Idris. ${ }^{13}$ Menurut Yazid al-Raqasyi, Nabi Nuh disebut Nuh karena ia suka meratap (menangis). ${ }^{14}$ Sementara al-Qur'an menyebutnya sebagai hamba yang suka bersyukur. ${ }^{15}$ Mungkin ia adalah tipe orang yang penuh keharuan dalam

\footnotetext{
11Muhammad Chirzin, Nur 'Ala Nur : 10 Tema Besar al-Qur'an Sebagai Pedoman Hidup (Jakarta: Gramedia, 2011), 132-137

${ }^{12}$ Ibn Kathir, Tafsìr Al-Qurān Al-'Azìim, vol. V (tt.: Mưassasah Qurțubah, 2000), hlm. 326.

${ }^{13}$ Muḥammad al-Rāzì Fakhr al-Dīn, Tafsìr Al-Fakhr Al-Rāzì, vol. 14 (Beirut: Dar al-Fikr, 1981), 153.

${ }^{14}$ Kathīr, Tafsìr Al-Qữān Al-'Azìm. Jilid V, hlm. 327.

${ }^{15}$ Al-Qur'an, 17:3
} 
mengungkapkan kesyukurannya sehingga ia suka menangis dalam kesyukurannya tersebut.

Nabi Nuh as dan kaumnya diperkirakan hidup pada 10.000 BC di lembah Eufrat dan Tigris. ${ }^{16}$ Lembah ini dikelilingi gunung-gunung tinggi yang mengalirkan mata air ke lembah tersebut. Daerah ini diperkirakan terletak di Mesopotamia, Irak Selatan. ${ }^{17}$ Jarak antara masa Nabi Adam as dan Nabi Nuh as adalah sepuluh abad. Sepanjang masa ini, menurut Ibn Katsir, belum ada kesyirikan, menyembah berhala. Semuanya taat dalam penyerahan diri kepada Allah (islam). ${ }^{18}$

Awalnya, pada masa Nabi Idris as, ia menunjuk beberapa muridnya untuk meneruskan ajarannya setelah ketiadaannya. Para murid ini melakukan tugasnya dengan sebaik-baiknya. Masyarakat yang mereka ajari juga senang dengan ajaran mereka sebab mereka bisa "membawa diri" (menyesuaikan diri) dengan masyarakat setempat. Setelah berselang beberapa waktu, para murid setia Nabi Idris ini pun meninggal dunia satu persatu dan pengikut-pengikutnya menjadi sedih. Untuk mengenang mereka, dibuatlah lukisan mereka yang dipajang di berbagai tempat termasuk tempat ibadah. Mereka pun saling menceritakan tentang nama-nama tokoh dan sejarah lukisan tersebut, yang disebut dengan Wadd, Suwa, Yaghus, Yauq dan Nasr. Lama-kelamaan, tujuan untuk mengenang kebaikan para tokoh tersebut berubah menjadikan tokohtokoh tersebut sebagai berhala (tuhan-tuhan) sesembahan mereka. Wadd berbentuk patung laki-laki sebagai simbol dewa keperkasaan, Suwa berbentuk perempuan sebagai symbol kecantikan atau kelembutan, Yaghus disimbolkan dengan singa yang menggambarkan kekuatan dan diyakini menyelamatkan dari kesulitan, Yauq disimbolkan kuda yang menggambarkan kecepatan untuk perjalanan dan peperangan serta Nasr disimbolkan dengan elang yang mampu "mencuri" berita langit dan menganugerahi umur panjang. ${ }^{19}$ Inilah awal

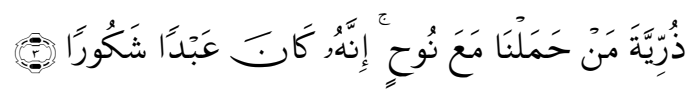

${ }^{16}$ Shabir Ahmed, "A History of Prophets and a Man of Noblest Character," October 2012, http://drshabbir.com, diakses pada 18 Agustus 2015.

${ }^{17}$ Rashid Ahmas Chaudhry, Hazrat Nub (Peace Be Upon Him) (UK: Islam International Publications Limited, 2005), hlm 7.

${ }^{18}$ Kathìr, Tafsir Al-Qữàn Al- 'Azïm, Jilid. V. hlm. 327.

${ }^{19}$ Chaudhry, Hazrat Nuh (Peace Be Upon Him), hlm 20. 
terjadinya penyembahan berhala di muka bumi. Berikut deskripsi Mehmet Dikmen; ${ }^{20}$

The Prophet Idris appointed some religious scholars of his ummah to guide people after him. These scholars did their best to guide the people living in various regions of the Arabian Peninsula and to show them the right way. People liked them soon due to their high ethics, nice preaching and advice. They liked talking to and listening to them, and benefited from them.

As those scholars died one by one, people felt very sorry. They always wanted to remember them and cherish the memory of them. They thought about what to do. In the end, they decided to erect their statues in squares of towns and hang their pictures on the walls of their houses. They started to gather around the statues at certain times. They told one another the words and advice of those scholars called Wadd, Suwa, Yaghus, Yauq, Nasr.

This deed, which started with a good intention, started to deviate from its purpose. The new generations that imitated what they saw from their fathers forgot about the reason why the statues were erected in squares and the pictures were hang on the walls. The pictures and statues ceased to be means and started to be aims. Instead of being a means of worshipping Allah, the pictures and statues started to be regarded as deities to be worshipped.

Thus, the custom of worshipping idols by forgetting Allah started in the world for the first time.

Dalam kondisi seperti inilah, Nabi Nuh as diutus untuk menyadarkan dan mengembalikan keyakinan kaumnya pada jalan yang benar. Oleh karena itulah pada awal-awal kisah Nabi Nuh as pada surah al-A'rāf: 59, Hūd: 26, alMukminūn: 23 dan Nūḥ: 3, selalu diawali dengan peringatan untuk menyembah Allah sebagai simbol eksistensi tunggal.

Nabi Nuh as pulalah disebut sebagai Rasul pertama yang memiliki tugas untuk menyebarkan hukum Tuhan (syari'ah). Hal ini dikarenakan kaumnya dianggap sebagai kaum pertama yang telah mencapai kemampuan untuk memahami sifat-sifat Tuhan. ${ }^{21}$ Mungkin, karena itu pula al-Qur'an (al-An'ām

${ }^{20}$ Mehmet Dikmen, "Prophet Nuh (Noah) (Peace Be Upon Him)," accessed August 18, 2015, www.questionsonislam.com. diakses pada 18/08/2015. Uraian serupa bisa dilacak dalam Ibn Kathīr, Tafsìr al-Qữān al- 'Ażìm, Jilid V, 327

${ }^{21}$ Chaudhry, Hazrat Nuh (Peace Be Upon Him), hlm. 7. 
(6): 84-86) menyebutkan nama Nabi Nuh as diawal dibandingkan nama-nama Nabi lainnya, sebagaimana berikut:
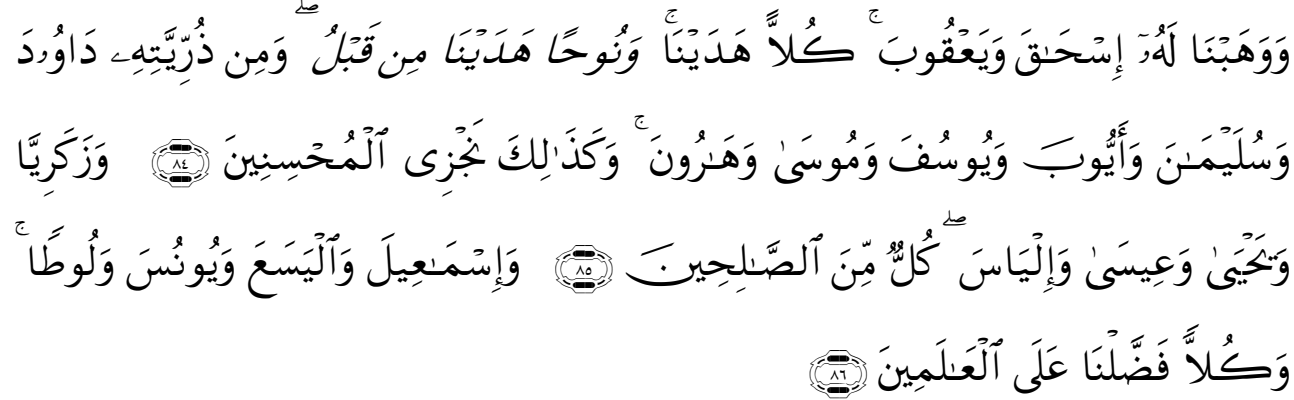

84. dan Kami telah menganugerahkan Ishak dan Yaqub kepadanya (Ibrahim). kepada keduanya masing-masing telah Kami beri petunjuk; dan kepada Nub sebelum itu (juga) telah Kami beri petunjuk, dan kepada sebahagian dari keturunannya (Nuh) Yaitu Daud, Sulaiman, Ayyub, Yusuf, Musa dan Harun. Demikianlah Kami memberi Balasan kepada orang-orang yang berbuat baik.

85. dan Zakaria, Yahya, Isa dan Ilyas. semuanya Termasuk orang-orang yang shaleh.

86. dan Ismail, Alyasa', Yunus dan Luth. masing-masing Kami lebihkan derajatnya di atas umat (di masanya),

Pada umur 40 tahun Nabi Nuh as diangkat sebagai Rasul. ${ }^{22}$ Nabi Nuh as diperkirakan berumur 950 tahun. Hal ini disinggung oleh al-Qur'an (al'Ankabūt :14). ${ }^{23}$ Namun menurut tafsir al-Thabari, ketika Nabi Nuh as diutus kepada kaumnya ia telah berusia 350 tahun, kemudian mendakwahi mereka 950 tahun, kemudian sesudah banjir besar ia hidup selama 350 tahun, jadi total usia beliau adalah 1650 tahun. ${ }^{24}$ Menurut Rashid Ahmad Chaudhry, memang sulit

${ }^{22}$ Menurutnya, total umur Nabi Nuh as adalah 1050 tahun. Berikut ungkapannya: "After Hz. Nub became a prophet at the age of 40, be fulfilled the duty of prophethood for 950 years fearlessly and continuously. Then, he witnessed the deluge and according to some strong narrations, he died after living sixty years following the deluge. Thus, his whole life is 1050 years". Dikmen, "Prophet Nuh (Noah) (Peace Be Upon Him)."

23 al-Qur'an, 29:14

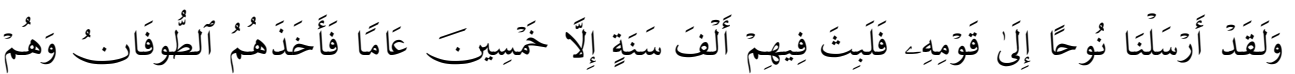
ظَبَلمُونَ

${ }^{24}$ Al-Ṭabarị, Tafsìr al-Thabari, Juz 18 (Kairo: Dar al-Hijr, 2001), 370 
untuk menentukan pastinya usia Nabi Nuh as, sebab, menurutnya, apa yang disinggung oleh al-Qur'an bukanlah umur fisik Nabi Nuh as, tetapi masa berlakunya ajaran Nabi Nuh as. Masa berlaku ini, menurutnya, mencapai masa Nabi Ibrahim as, hingga diberikan wahyu yang baru. Jadi, selama rentang masa itu yaitu masa Nabi Hud as, Nabi Saleh as, termasuk Nabi Ibrahim as, ajaran (syari'ah) yang diajarkan adalah syari'ah yang sama dengan Nabi Nuh as. Menurutnya, 50 tahun pertama dari kenabian Nuh as adalah masa kemajuan spiritual kaumnya sedangkan sisanya adalah masa kerusakan spiritual kaumnya hingga mencapai angka 900 tahun maka sempurnalah kerusakan tersebut. Sesudah ini barulah muncul wahyu baru. ${ }^{25}$

Meskipun Nabi Nuh dikirim kepada kaum yang telah mengalami perkembangan pemikiran yang mampu memahami sifat-sifat Tuhan, namun pemikiran mereka masih sederhana. Oleh karena itu, ajakan Nabi Nuh as untuk beriman kepada Allah hampir-hampir tidak ada bukti logis kecuali beberapa ayat yakni pada surah Nūh: 13-20 yang mengajak untuk memikirkan berbagai peristiwa penciptaan. Jadi ajaran Nabi Nuh as, lebih dominan pada ajakan dan ancaman saja. ${ }^{26}$

Oleh karena kesederhanaan berpikir ini pula, kaum Nuh as merasa sulit untuk menerima Nuh as yang merupakan manusia seperti mereka sebagai seorang utusan Allah, sebab dalam imajinasi mereka yang selayaknya menjadi utusan Allah adalah semacam malaikat atau sesuatu yang melampaui manusia. ${ }^{27}$

Kaum Nabi Nuh as adalah kaum yang membuat sistem kelas berdasarkan kekayaan dan status dalam hubungan sosialnya. Dalam kaum ini, ada kelas atas dan kelas bawah (masyarakat miskin). Kelompok kedua cenderung ditindas dan dihina, bahkan kelompok pertama marah dan enggan duduk bersama kelompok kedua. Mereka, dalam catatan al-Qur'an, bahkan meminta Nabi Nuh as mengusir kelompok kedua yang mayoritas telah beriman kepada Nabi Nuh as, namun Nabi Nuh as menolaknya. Pembagian kelas ini

${ }^{25}$ Chaudhry, Harrat Nuh (Peace Be Upon Him), hlm. 8.

${ }^{26}$ Untuk memahami perkembangan ajakan para Rasul tentang ajaran tauhid dari Nuh as hingga Nabi Muhammad Saw bisa dibaca dalam M. Quraish Shihab, Wawasan AlQur'an (Bandung: Mizan, 1996), hlm. 18-24.

${ }^{27} \mathrm{Al}-\mathrm{Qur}$ an, 11: 31

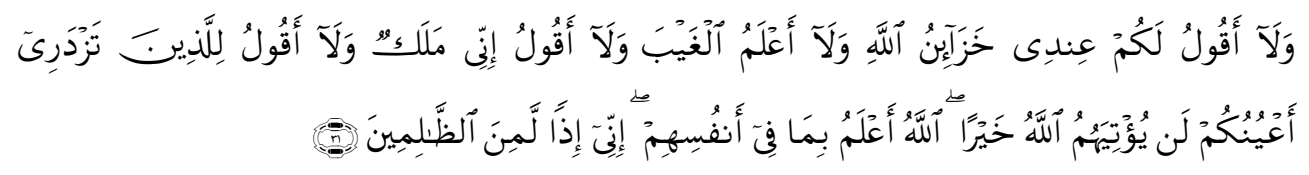


terekam dalam al-Qur'an 26:109-114. ${ }^{28}$ Kelompok elit (atas) terdiri dari para pemimpin kaum ${ }^{29}$, ulama (pemikir/pemimpin agama) ${ }^{30}$ dan orang-orang kaya ${ }^{31}$.

Nabi Nuh as adalah simbol manusia yang kerja keras dan tidak mudah menyerah. ${ }^{32}$ Ia juga cenderung bersabar, tabah, ikhlas dan berpasrah pada Allah meskipun ia terus diejek dan diremehkan. ${ }^{33}$ Dakwahnya yang sangat lama sekitar 950 tahun diperkirakan hanya menghasilkan 80 orang laki-laki ${ }^{34}$ atau 80 keluarga. ${ }^{35}$

${ }^{28}$ Berikut ayatnya:

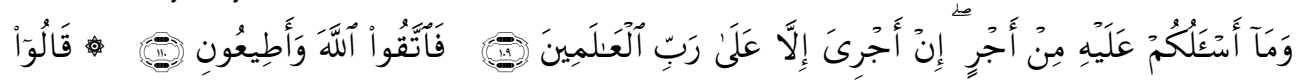

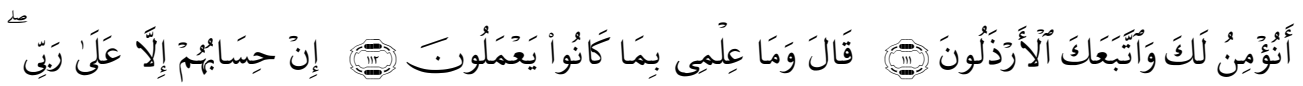
لَوْ تَشَعُرُونَ

${ }^{29} \mathrm{Al}-$ Qur'an, 11:27 \& 7:60

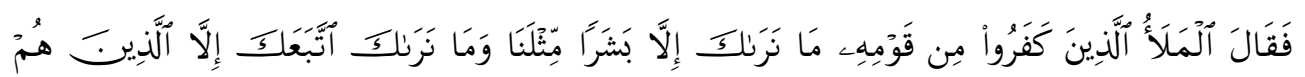

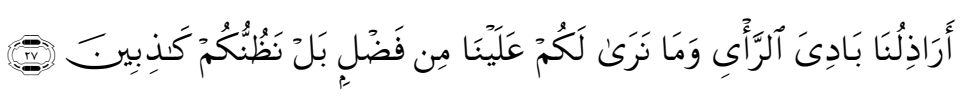

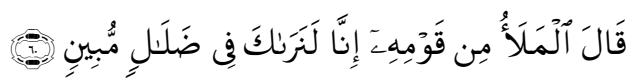

${ }^{30} \mathrm{Al}-\mathrm{Qur}$ 'an, 71: 23

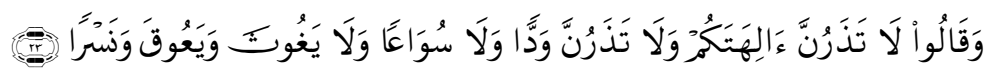

${ }^{31}$ Al-Qur'an, 71: 21

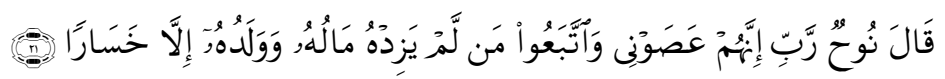

${ }^{32} \mathrm{Al}-\mathrm{Qur}$ 'an, 71: 5-9

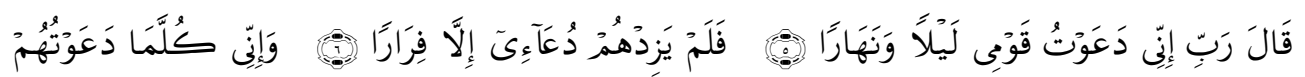

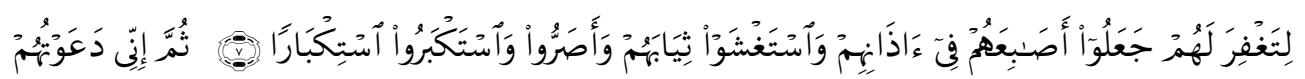

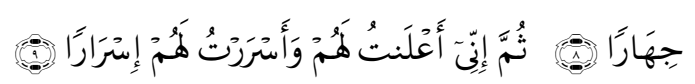

${ }^{33}$ Perhatikan pada tabel karakter Nabi Nuh as.

${ }^{34}$ Ibn Kathïr, Tafsìr al-Qữān al- 'Ażìm, Jilid V, 328

35 Dikmen, "Prophet Nuh (Noah) (Peace Be Upon Him)." Juga dalam Ibn Kathïr, Tafsìr al-Qữān al- 'Azīm, Jilid V, 441 
Oleh karena kedzaliman, kekufuran dan tertutupnya mata hati kaum Nabi Nuh as, termasuk seorang anaknya dan istrinya, akhirnya mereka dilanda banjir besar dan Nabi Nuh as diselamatkan oleh Allah. Diperkirakan mereka berlayar selama 150 hari $^{36}$ dan "mendarat" ada yang mengatakan di gunung Ararat dan ada juga yang menyebut al-Jüdi. Turki, Iran dan Armenia mengklaim bahwa kedua gunung tersebut berada di daerah mereka. ${ }^{37}$ Jadi, belum bisa dipastikan di mana tepatnya bahtera Nabi Nuh as mendarat.

\section{Memaknai Kisah Nuh As}

\section{a) Relasi Kisah Nuh As dengan Masyarakat Arab}

Sebelum memaknai kisah Nabi Nuh as ini, perlu untuk diketahui relasi masyarakat Arab sebagai penerima al-Qur'an pertama dengan konteks kisah Nuh as diatas. Pertama, masyarakat Arab yang pertama kali menerima alQur'an adalah masyarakat yang memiliki hubungan geneologis dengan Nabi Nuh as. Menurut Ibn Katsir, ketika kaum Nuh diselamatkan dari banjir besar, salah seorang diantara pengikutnya adalah Jurhum yang ber-lisan Arab $^{38}$ dan darinya muncul keturunan Arab. Namun menurut Dikmen, keturunan Arab, Persia dan Bizantium berasal dari anak Nabi Nuh as yang bernama Syam. ${ }^{39}$ Singkatnya, kisah Nabi Nuh as sangat penting bagi masyarakat Arab sebab merupakan asal-usul keturunan mereka.

Kedua, masyarakat Arab Quraisy yang sering melakukan perjalanan berdagang, ${ }^{40}$ ke negeri Syam pada musim panas dan ke negeri Yaman pada musim dingin, telah sering melihat dan mungkin berbagi kisah tentang reruntuhan peradaban masyarakat-masyarakat terdahulu, sebab mayoritas NabiNabi yang diceritakan dalam al-Qur'an yang ditentang umatnya dan

\footnotetext{
${ }^{36}$ Ibn Kathīr, Tafsìr al-Qữàn al-'Azìim, Jilid V, 441

${ }^{37}$ Chaudhry, Hazrat Nub (Peace Be Upon Him), hlm. 19.

${ }^{38}$ Ibn Kathì, Tafsìr al-Qurān al-'Azìm, Jilid V, 329

${ }^{39}$ After the deluge, human beings reproduced from the sons of $H z$. Nuh and the believers who were with him. According to a narration, among Nub's children, SHEM is the father of Arabs, Persians and Byzantines, HAM is the father of the Sudanese and JAPHETH is the father of Turks. Dikmen, "Prophet Nuh (Noah) (Peace Be Upon Him)."

${ }^{40}$ Kebiasaan berdagang masyarakat Arab Quraisy ini direkam oleh al-Qur'an dalam surah al-Quraisy (106): 1-4.
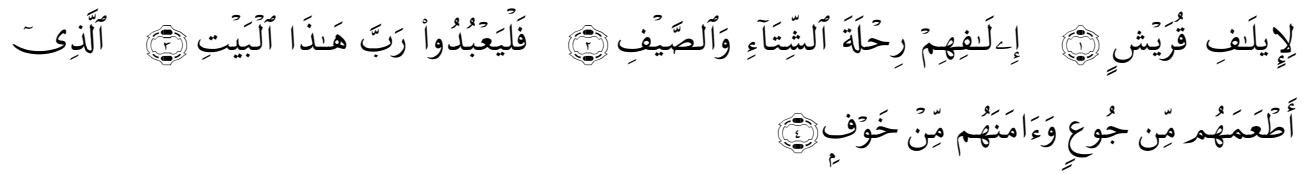
dihancurkan Allah diutus di daerah Timur Tengah. Oleh karena itu, mungkin saja masyarakat Arab telah mengetahui bekas-bekas sejarah seperti kaum 'Ad, Tsamud, termasuk juga kisah kaum Nabi Nuh as.

Ketiga, Mekkah saat itu adalah pusat peribadahan berhala. Ada lima sekte agama saat itu yaitu Watsani, Kristen, Magi, Yahudi dan Hanif. Selain itu juga, masyarakat Arab mempraktekkan animisme seperti keyakinan pada ruh, kekuatan yang tak terlihat, menyembah matahari dan pohon. Bahkan mereka kadang menggantungkan nasibnya pada sesuatu yang tidak masuk akal seperti mengundi nasib pada arah terbang seekor burung. Jika burung tersebut terbang ke arah kiri maka itu artinya berbahaya untuk melakukan perjalanan, dan jika ke kanan maka tanda baik untuk melakukan perjalanan. ${ }^{41}$ Pada kisah Nabi Nuh as, kaumnya juga suka menyembah berhala dan menolak diberi peringatan oleh Nabi Nuh as.

Keempat, masyarakat Arab adalah masyarakat yang mengusung prinsip 'așābiyyah (sikap fanatik pada kesukuan) sehingga sering menghasilkan peperangan antara suku dan menjadikan mereka terpecah belah. ${ }^{42}$

Kelima, masyarakat Arab cenderung melakukan penindasan, seperti tidak memberikan status yang baik pada perempuan. Perempuan dianggap sebagai bencana, sehingga tak jarang mereka, terutama di bani Tamim dan Asad, mengubur anak perempuan hidup-hidup. Selain itu mereka bisa mengawini perempuan tanpa batas, dan anak bisa mewarisi istri ayahnya. Suku Arab Quraisy juga suka melakukan riba dan penindasan terhadap suku Arab Badui, sehingga suku Arab Badui membalasnya dengan merampok kafilahkafilah dagang suku Arab Quraisy. Mereka juga mempraktekkan perbudakan dan penindasan pada yang lemah seperti penyiksaan pada Bilal yang telah masuk Islam. ${ }^{43}$

Berdasarkan kondisi ini, tentu kisah Nabi Nuh as sangat bermakna bagi masyarakat Islam Arab, sehingga mereka akan lebih mudah menghayati kisah yang disampaikan oleh al-Qur'an.

\section{Tabel I}

\begin{tabular}{|l|l|l|l|}
\hline \multirow{2}{*}{ No } & \multirow{2}{*}{ Kondisi Relasional } & \multicolumn{2}{|c|}{ Kondisi Identik } \\
\cline { 3 - 3 } & & Masa Nabi Nuh As & Masa Nabi Muhammad Saw \\
\hline
\end{tabular}

${ }^{41}$ Mohd Shukri Hanapi, "From Jahiliyyah To Islamic Worldview: In A Search Of An Islamic Educational Philosophy," International Journal of Humanities and Social Science, Special Issue, 3, no. 2 (January 2013), hlm. 215.

${ }^{42}$ Ibid., hlm 215-216.

43 Ibid. hlm. 216 


\begin{tabular}{|c|c|c|c|}
\hline 1 & $\begin{array}{c}\text { Nabi Nuh as adalah nenek } \\
\text { moyang masyarakat Arab }\end{array}$ & $\begin{array}{c}\text { Menyembah berhala: Wadd, } \\
\text { Suwwa', Yaghuts, Ya'uq dan } \\
\text { Nasr }\end{array}$ & Pusat penyembahan berhala \\
\hline 2 & $\begin{array}{c}\text { Telah mengetahui tentang } \\
\text { berbagai reruntuhan sejarah di } \\
\text { sekitar daerah Timur Tengah } \\
\text { karena perjalanan dagang dan } \\
\text { informasi kisah }\end{array}$ & $\begin{array}{c}\text { Dzalim: tidak mau duduk } \\
\text { bersama kaum kelas rendah \& } \\
\text { suka meremehkan mereka }\end{array}$ & $\begin{array}{c}\text { Dzalim: menindas perempuan, } \\
\text { suka balas dendam berlebihan \& } \\
\text { melakukan perbudakan }{ }^{44}\end{array}$ \\
\hline
\end{tabular}

b) Prinsip dan Nilai dari Kisah Nabi Nuh As 1)Sikap Tunduk Pada Eksistensi Tunggal

Ketundukan pada hakikat tertinggi yakni eksistensi tunggal merupakan pesan mendasar dari kisah Nuh as khususnya dan seluruh para Nabi yang diceritakan oleh al-Qur'an. Pesan ini sepertinya memang layak menjadi dasar kehidupan seluruh alam semesta, manusia khususnya, sebab pesan ini selain ditegaskan oleh kitab suci sendiri tetapi juga logis dan rasional.

Ketika seseorang berbicara tentang hakikat keberadaan realitas tertinggi maka secara tidak langsung ia akan berbicara tentang eksistensi tunggal ini. Bagaimana tidak, sesuatu yang mutlak tentu meniscayakan kesempurnaan dan kesempurnaan menafikan keterpisahan atau komposisi. Ia mesti sederhana dan tunggal. ${ }^{45}$ Jika terjadi kemen-dua-an maka pastilah itu bukan eksistensi mutlak sebab salah satu antara keduanya akan saling menafikan. ${ }^{46}$

\footnotetext{
${ }^{44}$ Berikut beberapa ungkapan tentang karakter masyarakat Arab ketika Islam datang; $A$ man can marry as many women as he pleased. In fact some of them had hundreds of wives.... When a member of a clan is murdered then that clan can retaliate by killing as many members of the murderer's clan.... Women were oppressed. They were not in receipt of inheritance from their husband or family's estate. This negation of inheritance is because women were regarded as weak and of no use to each clan or tribe... Nobility is earned because of wealth, stature and many children.... W ar as a result of pride and the 'asabiyyah spirit. In addition it is regarded as a noble profession... The master-slave relationship was full of oppression, humiliation and exploitation. As an example when a person failed to pay his debts or was a bankrupt then he can be made a slave. Slavery could also occur as a punishment on a criminal offense. It was also the case if a man from one tribe was captured by a stronger tribe, the man together with his tribe could be subjected to slavery. Ibid., 217-219.

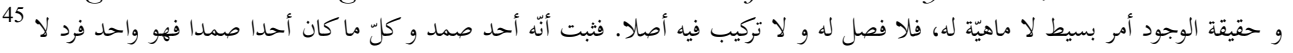
شريك له و لا تعدّد فيه
}

Mulla Shadra, Al-Mąāhir Al-Ilāhiyah. Islamic Republic of Iran: Mưassasah Būsitān Kitāb, 1387., hlm 77

${ }^{46}$ Al-Qur'an, 21: 22

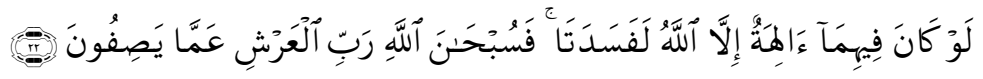


Sementara keberadaan realitas mutlak telah dibuktikan baik secara sederhana melalui kisah pengalaman-pengalaman spiritual para Nabi yang diceritakan kitab suci maupun secara filosofis. Filsafat skolastik misalnya, membuktikan hal ini dengan dasar argumen kosmologi, teleologi dan ontologi. Argumen kosmologi mendasarkan asumsi pada hukum kausalitas, sebab-akibat, yang diakhiri penyebab pertama yang mutlak. Inilah yang disebut dengan realitas tertinggi. Argument teleologi berdasar pada keseragaman dan keserasian alam, yang tidak dapat terjadi tanpa ada satu kekuatan yang mengatur keserasian itu. Argumen ontologi beranggapan bahwa kita memiliki ide tentang realitas mutlak.

Bagi Muhammad Iqbal, argumen di atas masih memiliki kelemahan. Argumen kosmologi yang menggunakan hukum kausalitas malah menghancurkan hukumnya sendiri sebab diakhiri dengan sebab yang tak bersebab. Padahal jika konsisten dengan hukum tersebut maka tak mungkin ada sebab yang tak bersebab sehingga mengakibatkan rantai yang tak berujung (tasalsul). ${ }^{47}$ Argumen teleologi hanya mengilustrasikan kelemahan realitas mutlak sebab ia layaknya seorang tukang yang telah selesai membuat sesuatu lalu mengaturnya saja lagi dan tidak mencipta lagi. Ia berarti tidak kreatif dan bebas. ${ }^{48}$ Argumen ontologi dengan menganggap bahwa realitas mutlak ada karena kita memikirkannya, juga tidak bisa membuktikkannya secara objektif, layaknya ketika seseorang mengatakan bahwa saya memiliki 500 juta dalam pikiran saya namun belum tentu bisa saya buktikan uang itu ada dalam kantong saya. $^{49}$ Baginya, realitas mutlak hanya bisa dibuktikan lewat pengalaman langsung melalui intuisi. Intuisi ini berbeda dengan intuisi para mistikus yang melenyapkan ego (diri) karena pertama-tama yang tersingkap secara kuat lewat intuisi adalah diri yang kreatif, bebas, dan imortal. Pengalaman ini pun terjadi dalam duration, perlangsungan waktu yang tunggal dan total bukan serial dan terkotak-kotak. Sebab peng-kotak-an dan serialitas itu adalah kerja konsepsi yang telah dipengaruhi oleh ruang dan waktu sehingga tidak original lagi.

\footnotetext{
${ }^{47}$ Logically speaking, then, the movement from the finite to the infinite as embodied in the cosmological argument is quite illegitimate; and the argument fails in toto. Muhammad Iqbal, The Reconstruction of Religious Thought in Islam (Zurich: International Relation and Security Network, 1930), hlm. 16. Diakses pada www. isn.ethz.ch.

${ }^{48}$ The argument gives us a contriver only and not a creator. Ibid.

${ }^{49}$ it is clear that the conception of existence is no proof of objective existence. As in Kant's criticism of this argument the notion of three hundred dollars in my mind cannot prove that I have them in my pocket. Ibid.
} 
Dengan demikian, kerja duration pada intuisi yang mampu menampung realitas mutlak ini juga merefleksikan ketunggalan realitas mutlak itu sendiri. ${ }^{50}$

Dalam kehidupan sehari-hari, kita sebagai manusia juga mengalami peristiwa tunggal tersebut. Masa lalu kita selalu hadir bersama masa kini dan masa kini berkelindan dengan masa depan kita. Faktanya kita sekarang adalah orang yang hadir di atas dunia dengan masa lalu yang telah melekat pada diri kita dan tidak bisa kita tolak. Ini sudah given. Namun masa kini kita memiliki berbagai kemungkinan (possibilities) untuk setiap pilihan, inilah masa depan. Iqbal mengungkapkan "it is an organic whole in which the past is not left bebind, but is moving along with, and operating in, the present. And the future is given to it not as lying before, yet to be traversed; it is given only in the sense that it is present in its nature as an open possibility". ${ }^{51}$

Sementara al-Qur'an dengan gamblang menggambarkan pengalaman realitas mutlak dan tunggal ini dengan ungkapan

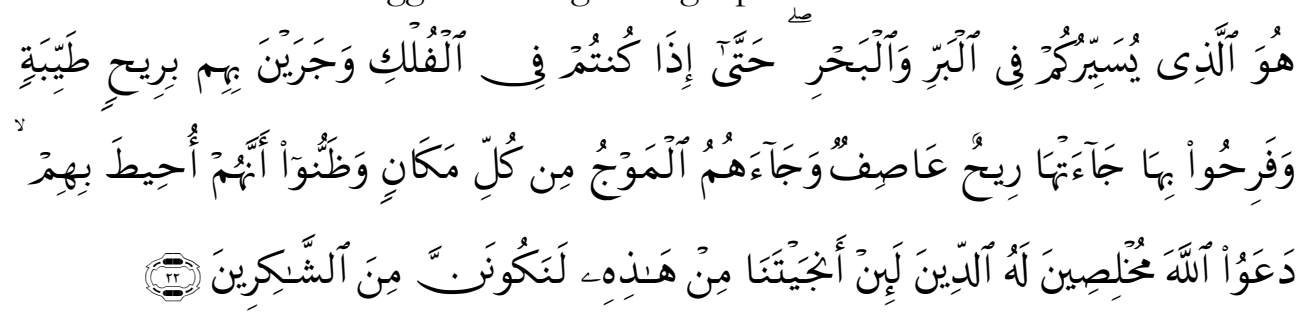

22. Dialah Tuhan yang menjadikan kamu dapat berjalan di daratan, (berlayar) di lautan. sehingga apabila kamu berada di dalam bahtera, dan meluncurlah bahtera itu membawa orang-orang yang ada di dalamnya dengan tiupan angin yang baik, dan mereka bergembira karenanya, datanglah angin badai, dan (apabila) gelombang dari segenap penjuru menimpanya, dan mereka yakin bahwa mereka telah terkepung (bahaya), Maka mereka berdoa kepada Allah dengan mengikhlaskan ketaatan kepada-Nya semata-mata. (mereka berkata): "Sesungguhnya jika Engkau menyelamatkan kami dari bahaya ini, pastilah kami akan termasuk orang-orang yang bersyukur".

\footnotetext{
${ }^{50}$ Isra dan Mi'raj mungkin saja sebuah perisitiwa yang terjadi pada intuisi Nabi Muhammad saw dan dalam duration sehingga perjalanan, yang jika dikalkulasi oleh konsepsi akan sangat panjang dan luar biasa ini, terjadi dalam waktu "sekejap".

${ }^{51}$ Iqbal, The Reconstruction of Religious Thought in Islam. hlm. 25
} 


\section{2) Relasi Realitas Mutlak dan Ciptaan}

Sebagaimana uraian sebelumnya, ketika pengalaman pada eksistensi tunggal tidak bisa dilepaskan dari seluruh kehidupan maka sikap tunduk pada eksistensi tersebut adalah sebuah keniscayaan. ${ }^{52}$ Menafikan sikap ini akan menghasilkan khaos, ketidakberaturan, dan kedzaliman. M. Quraish Shibab menyatakan bahwa tanpa ketundukan pada eksistensi tunggal ini maka keteraturan alam semesta akan hancur, sebagaimana yang diungkapkannya; rangkaian pertanyaan berikut dapat menjadi salah satu bukti tentang kebutuhan akalnya terhadap akidah ini. Pertanyaan dimaksud adalah: "Siapa yang menjamin bila Anda melontar ke depan, maka batu itu tidak mengarah ke belakang? Apa yang menjamin bahwa air selalu mencari tempat yang rendah? Apa yang mengantar ilmuwan untuk memperoleh semacam, kepastian, dalam langkah-langkahnya?" Kepastian tersebut tidak mungkin dapat diperoleh kecuali melalui keyakinan tentang wujud Tuhan Yang Maha Esa. Karena jika Tuhan berbilang, maka sekali tuhan ini yang mengatur alam dan menetapkan kehendak-Nya dan kali lain tuhan yang itu. Apa yang menjamin kepastian itu, seandainya Tuhan Yang mengatur hukum-hukum dan tata kerja alam raya, juga butuh kepada sesuatu? Sudah dapat dipastikan tidak ada yang dapat menjamin! ${ }^{53}$

Selain itu, sikap menafikan eksistensi tunggal ini juga akan menghasilkan kedzaliman. Pertama, kedzaliman terhadap diri sendiri. Kedua, kedzaliman terhadap orang lain dan sekitarnya.

Jika kita memperhatikan uraian al-Farabi misalnya dalam penciptaan maka setiap penciptaan saling terhubung dan bertingkat. Al-Farabi menunjukkan bahwa realitas mutlak ketika memikirkan dirinya sendiri melimpahkan eksistensi kedua atau akal pertama dan ketika ia berpikir tentang eksistensi pertama maka muncullah eksistensi ketiga dan ketika memikirkan dirinya sendiri maka muncullah langit pertama. Eksistensi ketiga atau akal kedua hingga eksistensi kesepuluh atau akal kesembilan memiliki aktivitas seperti eksistensi kedua atau akal pertama yaitu memikirkan eksistensi pertama,

52Perhatikan misalnya pada Al-Qur'an al-Ra'd (13) : 15 dan al-Fuṣsilāat (41) : 11.

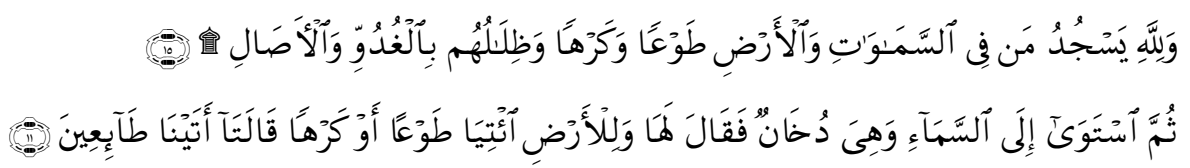

${ }^{53}$ Shihab, Wawasan Al-Qur'an, hlm. 37. 
yang menghasilkan eksistensi-eksistensi selanjutnya, dan memikirkan dirinya yang menghasilkan berbagai planet. Berikut ilustrasinya: ${ }^{54}$

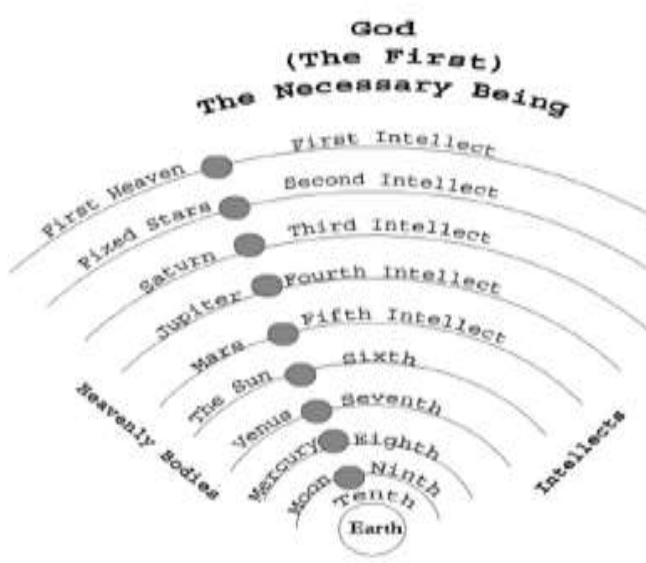

Hingga pada wujud kesebelas atau akal sepuluh, akal-akal terhenti. Dari akal kesepuluh inilah muncul bumi, roh dan materi pertama yang menjadi dasar dari empat unsur; api, udara, air dan tanah.

Berdasarkan hal di atas, ruh/jiwa manusia merupakan penyinaran cahaya eksistensi mutlak yang terakhir dan puncak tertinggi dari proses pencapaian tingkatan materi. Oleh karena itu, jika manusia menjauhkan diri dengan mengingkari realitas eksistensi tunggal maka itu sama saja menjauhkan diri dari sumber cahaya dan menjadikan manusia terjebak pada area material sehingga ia selalu berada dalam kegelapan. Sebagaimana orang yang terjebak dalam kegelapan tanpa cahaya maka ia akan mudah tersesat dan kebingungan. Tentu ini adalah sebuah kedzaliman terhadap diri sendiri.

Kegelapan jiwa seperti ini sangat riskan dan bisa menghasilkan sikap dzalim terhadap orang lain dan sekitarnya sehingga muncullah sifat-sifat jahat seperti rasa sombong, angkuh, suka menindas dan meremehkan maupun merusak. Ini kondisi non-autentik menurut Heidegger. Baginya, cara berada manusia yang mendasar adalah rasa cemas (angst) yang meniscayakan tindakan memahami dan melalui tindakan ini muncullah sikap peduli (care) yang

${ }^{54}$ Mashhad al-Allaf, The Essential Ideas of Islamic Philosophy (USA: The Edwin Mellen Press, 2006), hlm. 120. 
merupakan struktur totalitas mendasar bagi manusia ${ }^{55}$, sehingga upaya hidup bersama dalam kepedulian dan memilih kebaikan adalah hidup yang autentik. ${ }^{56}$ Menafikan hal ini sama dengan menafikan Being itu sendiri dan ini mengakibatkan hilangnya makna keberadaan manusia, sebab menurutnya, Dasein dan Being saling terkait. Heidegger, dikutip Riyanto, mengatakan "Dasein and Being always coexist, in the sense that the latter depends on the former for its revealing, and the former on the later for its meaning". ${ }^{57}$

Dengan demikian, kejahatan adalah wilayah yang tidak terkena pancaran cahaya eksistensial sehingga wilayah tersebut menjadi gelap, namun kegelapan ini pun bergradasi. Oleh karena itu, semakin jauh dari pancaran cahaya eksistensial maka semakin gelap keadaannya dan semakin dekat dengan cahaya maka kegelapan semakin pudar dan cenderung menghilang dalam cahaya eksistensial. Oleh karena itu, orang yang menjadi jahat maka ia terjebak dalam kegelapan yang tidak dipancari oleh cahaya eksistensial.

Di lain hal, Martin Buber juga mengingatkan bahwa pada hakikatnya keberadaan manusia di alam semesta ini tidak bisa melepaskan dirinya dari relasi Tuhan, sesama manusia dan alam sekitarnya. Manusia sebagai subjek tidak bisa mewujudkan kesadarannya dan akan kehilangan kehadirannya jika mengabaikan relasi-relasi di atas. Ringkasnya bisa diungkapkan dengan istilah perjumpaan aku dengan engkau menjadikan aku ada. Dalam ungkapan Buber "there is no I taken in itself, but only the I of the primary word of I-Thou and the I of the primary word of I-it'. ${ }^{58}$

Akhirnya, bersikap tunduk dan menjalin relasi kepada realitas mutlak akan membawa kebaikan bagi diri sendiri, orang lain dan sekitarnya. ${ }^{59}$

\footnotetext{
${ }^{55}$ Care serves as a primordial structural totality...Thus, again, our existence is always constituted by care. Bambang Riyanto, "Care: The Ontological Foundation of Dasein," Majalah Filsafat Driyarkara, STF Driyarkara, XXV, no. 2 (2001), hlm. 9, 14, 19.

56 Ibid, hlm 19.

57 Ibid, hlm 14.

58 Martin Buber, I and Thou, Trans by Ronald Gregor Smith, (Edinburgh: T. \& T.Clark, 1937), hlm. 4.

${ }^{59}$ Contoh sederhana dari hubungan semua ciptaan Tuhan adalah ketika kita membuang sampah sembarangan maka itu bisa mengakibatkan banjir untuk orang lain dan merusak alam sekitar. Padahal dalam tradisi Islam ada ungkapan kebersihan adalah bagian dari iman.
} 


\section{3) Relasi Menurut al-Qur'an Berdasarkan Keyakinan \& Perbuatan}

Ketika Nabi Nuh as menyaksikan anaknya diantara gelombang banjir besar, Nabi Nuh as mengajaknya bersamanya. Namun anaknya menolak dan tenggelam dibawa banjir. Akhirnya Nabi Nuh as merasa sedih dan "protes" pada Allah, yang kemudian Allah menjawab bahwa anaknya melakukan perbuatan tidak shalih. ${ }^{60}$

Informasi ini mengindikasikan bahwa relasi dalam tradisi Islam dan sesudah dunia ini didasarkan pada relasi keyakinan dan perbuatan bukan relasi nasab (keturunan). Oleh karena itu, dalam kisah di atas, meskipun anak Nabi Nuh as dan isterinya di bawah naungan dan keluarga seorang Rasul tetapi tidak bisa menyelamatkan mereka dari banjir besar. ${ }^{61}$ Bahkan al-Qur'an juga mengingatkan bahwa pada hari akhir nanti tidak ada lagi persaudaraan berdasarkan nasab kecuali takwa. ${ }^{62}$

Singkatnya, dalam al-Qur'an hubungan hari akhir didasarkan pada iman (keyakinan) dan amal perbuatan, àmanū wa 'āmilū al-șâlihăt. Hal ini menjadi penting, sebab secara gradasi Mulla Shadra di atas, kehidupan itu bertingkat. ${ }^{63}$

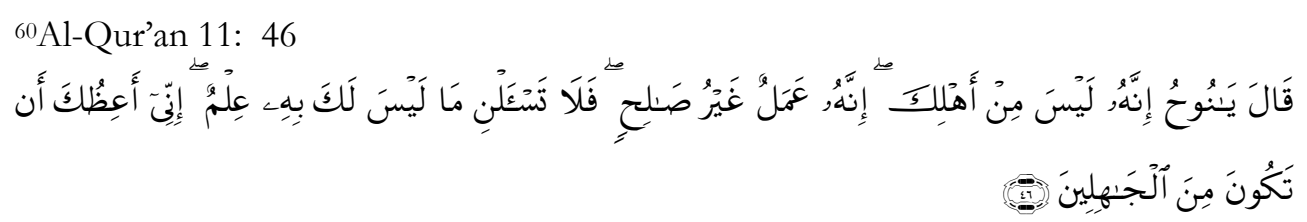

${ }^{61} \mathrm{Al}$-Qur'an menyinggung beberapa keluarga yang berada di bawah asuhan orang shaleh yang menjadi jahat, dan sebaliknya. Al-Qur'an 66: 10-11

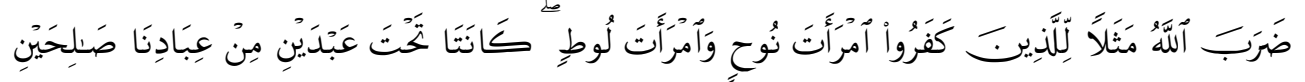

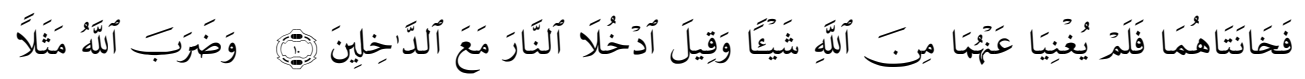

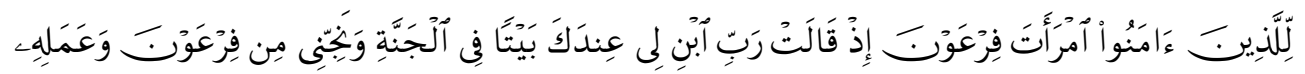

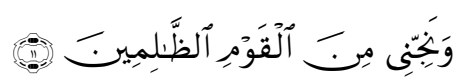

62 Al-Qur'an $43: 67$

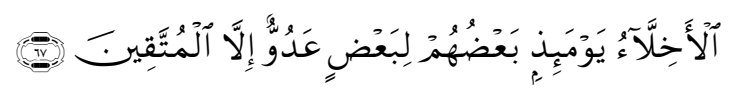

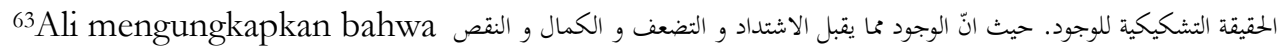
Ali al-Haj Hasan, al-Hịmah al-Muta'àliyah 'ind Saḍ Mutạălihin al-Shiräzīi (tt. : Dar alHadi, 2005), 293 
Ketika seseorang meninggal dunia, sebenarnya ia tidak mati namun mendaki kepada tingkat yang lebih tinggi dengan struktur yang lebih tinggi (spiritual). Keimanan dan perbuatan adalah sesuatu yang bernilai spiritual, sebab nilai amal tersebut terkait dengan "niat" di hati. Tidak ada yang memahami hal ini kecuali diri pelaku dan penciptanya. Oleh karena itu, nilai ini akan terlihat ketika tahapan atau dunia spiritual itu telah hadir atau tersingkap. Nilai yang akan dihadirkan oleh dunia spiritual dari perbuatan dan niat yang dibentuk dalam batin akan menghasilkan bentuk yang beragam. Sebagian berbentuk binatang dan sebagian lain berbentuk manusia. Sebuah riwayat menceritakan bahwa Iblis berkata: "Jika ia (manusia) menang atas-ku, maka ketika shalat berjamaah aku cambuk dia dengan 'lijām' [cambuk] lalu aku angkat kepalanya sebelum imam mengangkat kepalanya. Aku letakkan ia hingga mendahului imam. Kamu tahu bahwa siapa yang melakukan itu, batal-lah shalatnya dan Allah akan mengganti kepalanya dengan kepala keledai pada hari kiyamat nanti". ${ }^{64}$

Nabi Muhammad saw sendiri menyatakan bahwa "manusia dikumpulkan pada hari kiamat dalam berbagai rupa sesuai dengan kecenderungan jiwanya." ${ }^{65}$

Terjadinya pembentukan ini dikarenakan pada tahap spiritual kekuataan jiwa lebih dominan dibandingkan kekuatan jasad (material) sehingga kecenderungan batin yang direfleksikan dengan tindakan (perbuatan) yang berulang-ulang pada alam lahir akan menunjukkan hakikat sebenarnya ketika sampai pada tahap spiritual.

Selain itu, tindakan atau perbuatan memang merupakan aspek fundamental dari manusia, sebab lewat tindakanlah manusia dapat menunjukkan keputusannya dan memunculkan kebebasannya dan kreativitasnya. Semakin kreatif tindakannya maka akan semakin unik dan berharga seseorang. Tuhan sendiri adalah pelaku tindakan yang paling kreatif dan unik sehingga ia selalu menjadi rujukan dan contoh sekaligus menandakan keabsolutan diri-Nya. ${ }^{66}$

64 Ibnu 'Arabi, Misteri Kun (Surabaya: Risalah Gusti, 2001), hlm 117.

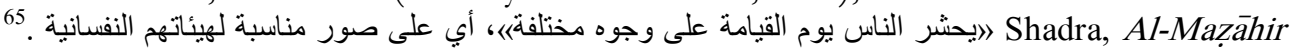
Al-Ilāhiyah. Islamic Republic of Iran: Mu assasah Büsitān Kitāb, hlm. 129. ${ }^{66} \mathrm{Al}-\mathrm{Qur}$ 'an 55: 29

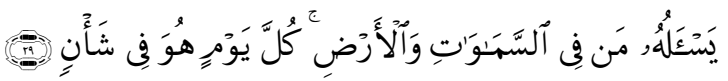


Seseorang yang terus menerus mengulangi tindakannya juga akan mampu menjadi ahli sehingga secara identitas pekerjaan itu dilekatkan pada dirinya. Misalnya, A adalah seorang alumni filsafat namun kemahirannya dalam menangani problem software komputer menjadikannya lebih dikenal sebagai ahli komputer dibandingkan alumni filsafat.

Dengan demikian, relasi yang didasarkan pada keyakinan dan perbuatan, menurut al-Qur'an akan terwujud pada dunia spiritual seperti alam barzakh dan hari kiamat, dan berbeda dengan kondisi dunia yang mendasarkan relasi pada nasab (keturunan).

\section{4) Sabar Tanpa Batas}

Berdasarkan kisah al-Qur'an, Nabi Nuh as bisa dikategorikan sebagai seorang yang sabar tanpa batas. Kesabaran ini bisa diindikasikan dari sikap pasrah totalnya kepada Tuhan dan usahanya yang tiada henti. Meskipun ia harus berdakwah dengan waktu yang lama dan mendapatkan pengikut yang sedikit, ${ }^{67}$ Nabi Nuh as tetap berdakwah dengan gigih. Hal ini diceritakan oleh al-Qur'an 71: 5-21, dimana Nabi Nuh as diinformasikan berdakwah siang dan malam, sembunyi-sembunyi dan terang-terangan tetapi hasilnya nihil dan pertentangan belaka. Akhirnya Nabi Nuh as mengeluhkan hal ini kepada Tuhan dengan ungkapannya:

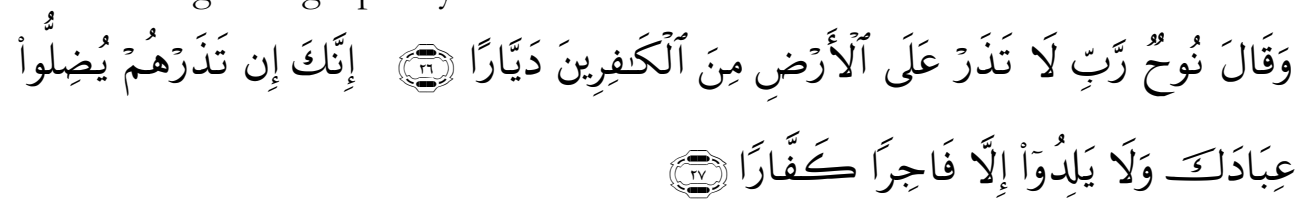

26. Nuh berkata: "Ya Tuhanku, janganlah Engkau biarkan seorangpun di antara orang-orang kafir itu tinggal di atas bumi.

27. Sesungguhnya jika Engkau biarkan mereka tinggal, niscaya mereka akan menyesatkan hamba-hamba-Mu, dan mereka tidak akan melahirkan selain anak yang berbuat ma'siat lagi sangat kafir.

Lalu apakah keluhan ini menjadikan Nabi Nuh as dalam kategori orang yang tak sabar atau sabarnya berbatas. Ibn 'Arabi dalam hikāyah al-Iblis menyatakan bahwa Nabi Muhammad saw ketika berdialog dengan Iblis bertanya :

${ }^{67}$ Al-Qur'an $11: 36$ 
وما يدريك انه صبور؟ فقال : يا تُحَّم اذا شكا ضرّه لمخلوق مثله ثلاثة ايام لم يكتب الله له<smiles></smiles>

(Wahai Iblis) bagaimana kamu tahu bahwa ia sabar? Iblis menjawab: Wahai Muhammad, jika ia mengeluhkan kesulitannya kepada makhluk sesamanya selama tiga hari maka Allah tidak akan mencatatnya amalnya dalam golongan orang yang sabar. ${ }^{68}$

Berdasarkan pendapat ini, maka Nabi Nuh as adalah orang yang sabarnya tanpa batas, karena ia hanya mengeluhkan masalahnya kepada Tuhan bukan kepada makhluk. Dengan demikian, nilai kesabaran Nabi Nuh as yang bisa diambil adalah kepasrahan totalnya kepada Allah dan usahanya yang tiada henti, serta keluh kesahnya yang hanya ditujukan kepada Allah hingga akhirnya ia, dalam tradisi Islam dikenal sebagai salah satu Nabi Ulul 'Adzmi (Nabi yang memiliki keistemewaan).

\section{Simpulan}

Kisah Nabi Nuh as di dalam al-Quran menunjukkan makna yang cukup variatif. Bagi masyarakat Arab, sebagai masyarakat pertama yang menerima wahyu dari Nabi Muhammad saw, kisah Nabi Nuh as sangat relevan dan sangat dibutuhkan sebab Nabi Nuh as adalah bagian dari nenek moyang mereka dan secara historis mereka terbiasa mendengar dan atau melihat berbagai sisa-sisa peninggalan peristiwa sejarah tersebut saat mereka melakukan perjalanan dagang ke berbagai daerah Timur Tengah sehingga kisah seperti ini lebih melekat dan bermakna bagi mereka ketika al-Quran mengingatkan mereka tentang kisah ini.

Kemudian, secara filosofis, kisah ini menunjukkan makna yang menekankan pentingnya sikap kepasrahan pada eksistensi Tunggal (Tuhan), karena secara rasional, prinsip ini mampu menumbuhkan sikap apresiatif terhadap sesama makhluk yang ada di alam ini sehingga mampu menafikan penindasan dan kerusakan di atas semesta ini. Oleh karena itu, secara tidak langsung, hal ini juga menggambarkan bagian dari proses keberhasilan pembangunan peradaban bagi manusia, dimana moral baik akan mampu menggiring dan melestarikan kejayaan sebuah peradaban dan moral buruk akan menghancurkan manusia tersebut.

${ }^{68}$ Muhyiddin Ibnu 'Arabi, Misteri Kun: Syajaratul-Kaun (Surabaya: Risalah Gusti, 2005), hlm. 109. 
Dengan demikian, al-Quran sudah berupaya mengajarkan prinsipprinsipnya dengan pendekatan yang sederhana, historis sekaligus filosofis sehingga kita dituntut untuk terus merenungkannya agar tercipta makna-makna baru yang relevan bagi kebutuhan kita pada setiap waktu dan zaman. Wallāhu a'lam

\section{Daftar Pustaka}

Ahmed, Shabir. "A History of Prophets and a Man of Noblest Character," October 2012. http://drshabbir.com,.

Allaf, Mashhad al-. The Essential Ideas of Islamic Philosophy. USA: The Edwin Mellen Press, 2006.

'Arabi, Ibnu. Misteri Kun. Surabaya: Risalah Gusti, 2001.

Attamimi, Faisal. "Hermeneutika Gadamer Dalam Studi Teologi Politik." Hunafa: Jumal Studia Islamika 9, no. 2 (Desember 2012).

Bertens, Kees. Filsafat Barat Abad XX: Inggris-Jerman. Jakarta: Gramedia, 1990.

Bleicher, Josef. Contemporary Hermeneutics. London: Routledge \& Kegan Paul, 1980.

Buber, Martin, and Trans by Ronald Gregor Smith. I and Thou. Edinburgh: T. \& T.Clark, 1937.

Chaudhry, Rashid Ahmas. Hazrat Nuh (Peace Be Upon Him). UK: Islam International Publications Limited, 2005.

Dikmen, Mehmet. "Prophet Nuh (Noah) (Peace Be Upon Him)." Accessed August 18, 2015. www.questionsonislam.com.

Fakhr al-Dīin, Muhammad al-Rāzì. Tafsìir Al-Fakhr Al-Rāzī. Vol. 14. Beirut: Dar al-Fikr, 1981.

Hanapi, Mohd Shukri. "From Jahiliyyah To Islamic Worldview: In A Search Of An Islamic Educational Philosophy." International Journal of Humanities and Social Science, Special Issue, 3, no. 2 (January 2013).

Hidayat, Aat. "Epistemologi Hermeneutik Hans-Georg Gadamer: Menyelami Kedalaman Tradisi, Menuai Kelezatan Makna," n.d. https://aathidayat.wordpress.com.

Ibnu 'Arabi, Muhyiddin. Misteri Kun: Syajaratul-Kaun. Surabaya: Risalah Gusti, 2005.

Iqbal, Muhammad. The Reconstruction of Religious Thought in Islam. Zurich: International Relation and Security Network, 1930. www. isn.ethz.ch.

Kathīir, Ibn. Tafsìr Al-Qữān Al-'Azìim. Vol. V. tt.: Mưassasah Qurțubah, 2000. 
Qatțān, Mannā' al-. Mabāhith Fì “Ulūm Al-Qur"ān. tt.: al-Manshūrāt al'Așr al-Ḥadith, 1973.

Redaksi. "Bumi Kini Tidak Lagi Sendiri." Banjarmasin Post, July 26, 2015.

Riyanto, Bambang. "Care: The Ontological Foundation of Dasein." Majalah Filsafat Driyarkara, STF Driyarkara, XXV, no. 2 (2001).

Shadra, Mulla. Al-Mazāhir Al-Ilāhiyah. Islamic Republic of Iran: Mu assasah Büsitān Kitāb, 1387.

Shihab, M. Quraish. Wawasan Al-Qur'an. Bandung: Mizan, 1996.

Sumaryono, E. Hermeneutika: Sebuah Metode Filsafat. Yogyakarta: Kanisius, 2002.

Yahya, Harun. Pustaka Sains Populer Islami 8: Jejak Bangsa-Bangsa Terdabulu. Bandung: Dzikra, 2004. 